\title{
ANATOLIA AND THE BALKANS, ONCE AGAIN - RING-SHAPED IDOLS FROM WESTERN ASIA AND A CRITICAL REASSESSMENT OF SOME 'EARLY BRONZE AGE' ITEMS FROM IKIZTEPE, TURKEY
}

\begin{abstract}
Summary. The ring-shaped idol pendant, a distinctive type of Chalcolithic ritual (?) jewellery, is discussed with regard to its chronology in the Balkans in light of its occasional appearance in Asia Minor. Known from domestic contexts, funerals and hoards (?), none of the so far documented Anatolian pendants (clearly another aspect testifying to the well-known AnatolianBalkan connections in the fourth millennium BC) can be dated later than the Late Chalcolithic/Early Bronze Age I. This fact provides further evidence for the developing hypothesis that certain inventories from İkiztepe, the only prehistoric reference site on the Turkish Black Sea coast excavated on a large scale, need some profound chronological redating. Selected features and levels dated to 'Early Bronze Age II-III' at Ikiztepe seem to be several centuries older than currently believed, which has implications for the overall chronological range of these pendants.
\end{abstract}

Tracing cultural interaction between Asia Minor and the south-eastern European landscapes is one major focus of prehistoric research both in Anatolia and beyond the Bosporus. Thanks to numerous collaborations, a different light has been shed on the flux and exchange of technological innovations, the adaptation of settlement patterns, and the possible periods of larger-scale migration that forged the cultural and ideological outline of the Orient and the Occident on their boundary in prehistoric times (cf. Özdoğan 1989; Nikolov 1993; Srejović 1993; Özdoğan 1999). The 'transitional' periods in particular, or what we consider 'transitional' for lack of better understanding, have been extensively discussed: the dynamics of change in the Neolithic/ Chalcolithic (seventh/sixth millennium BC) together with the discussion of Late Chalcolithic features are the two issues which have been developed most by scholars over the past two decades (cf. Bankoff and Winter 1990; Parzinger 1992; Steadman 1995; Maran 1998 with further literature). This paper will contribute another on Balkan-Anatolian relations, by drawing attention to an item that has not been appreciated sufficiently so far: the ring-shaped idol.

In a broader chronological dimension, these distinctive, tentatively 'ritual' items (assumed through their frequent association with elaborate burials and hoards; cf. below) might 
help us to contribute to defining the still hotly debated 'Late Chalcolithic' period in Asia Minor. Strictly speaking, the lack of a well-defined chronological terminology and the scarcity of detailed typological studies have caused some serious confusion in assessing both domestic and funeral features pre-dating the beginning of the Anatolian 'Early Bronze Age', usually to be placed around 3000 BC (cf. Schoop 2005, 14-17; with a valuable attempt to re-evaluate mainly 'Chalcolithic' pottery assemblages in western and central Anatolia).

However, indicators considered traditionally for south-east European/Balkan-Anatolian connections in the fourth millennium BC, our main chronological period of interest here, include pottery styles (cf. Parzinger 1993a, 236-8; Thissen 1993; Nikolov 2002; Nikolov 2003, 31-9), clay objects such as female figurines (Mantu 1993; Nikolov 2003, 58-66; Hansen 2005) and abstract ring- 'idols' or pendants made of gold or - more seldom - lead and silver (Fig. 2).

These idols have a broad chronological and spatial range, with late variants known from Late Chalcolithic and Early Bronze Age burial contexts in central Europe (cf. Behrens 1970, 30-3; Kytlicová 1960, 445 for bone idols in advanced third-millennium 'Schönfeld' and Bell Beaker contexts). But the distinctive type to be discussed here, with a flaring, sometimes truncated 'head' and a centrally pierced circular body, is best attested in the eastern and south-eastern European Chalcolithic, in the final centuries of the fifth and the first half of the fourth millennia BC (Makkay 1976; Jovanović 1996). Although known mainly from hoards and therefore difficult to pinpoint chronologically except by associative dating (cf. Fig. 2, nos. 2, 6), a number of ring-idols also come from burial context, accompanying Chalcolithic inhumations. Ring-shaped gold pendants with the typological features mentioned above are known, for example, from the cemetery at Tibava, east Slovakia (assigned to the fifth-millennium Tiszapolgár culture), from burials dated to the slightly later Bodrogkeresztúr horizon (Makkay 1976, 251-2, but with outdated attempts to correlate the finds with the Aegean Bronze Age; for an actual chronological assessment see Parzinger 1992; Raczky 1995); or even better from Varna, Bulgaria (Ivanov and Avramova 2000, 38 ['grave'/cenotaph 15]; 41 ['grave'/cenotaph 36]; 51 [grave 48; 'grave'/cenotaph 97]). The burials from these cemeteries, after some debate about their absolute chronology (cf. Weisshaar 1982; Zanotti 1984/85), can now be securely assigned to the early 'Karanovo-Gumelniţa-Kodzadermen VI' cultural complex, and thus dated to about 4100-3900 BC (Lichardus 1991; Todorova 1999, 245-6).

The chronological range of these pierced metal pendants is therefore defined through the Tiszapolgár/Varna cultures at the lower end and the Bodrogkeresztúr horizon at the upper end of our timeline, giving us a chronological span running from approximately 4500-3500 BC. No 'Balkan style' ring-pendants are attested in the following Boleráz/Cernavoda III horizon of eastern Europe, starting about 3500 BC (Maran 2000, 185). Identical pendants of an equally early date, including some made from silver, are likewise known from caves in the Aegean koine, now re-examined and convincingly redated by Joseph Maran (2000).

Under these circumstances, it would not be surprising to come across these distinctive artefacts in Anatolia also, since economic and ideological relations between the Balkans, southeast Europe, the Aegean world and Asia Minor are now well attested, especially for the fourth millennium, thanks to the intensive research of past decades. In particular the Turkish Black Sea littoral, a natural seaferrying link between northern Anatolia and south-east Europe, could be expected to yield some evidence for the exchange of goods, fashions, ideas and people in the Pontic region (cf. Höckmann 2003).

Ring-pendants of the 'east/south-east European' type sketched above can serve as one indicator of this exchange. They have surfaced occasionally in Asia Minor (cf. Fig. 1): one 


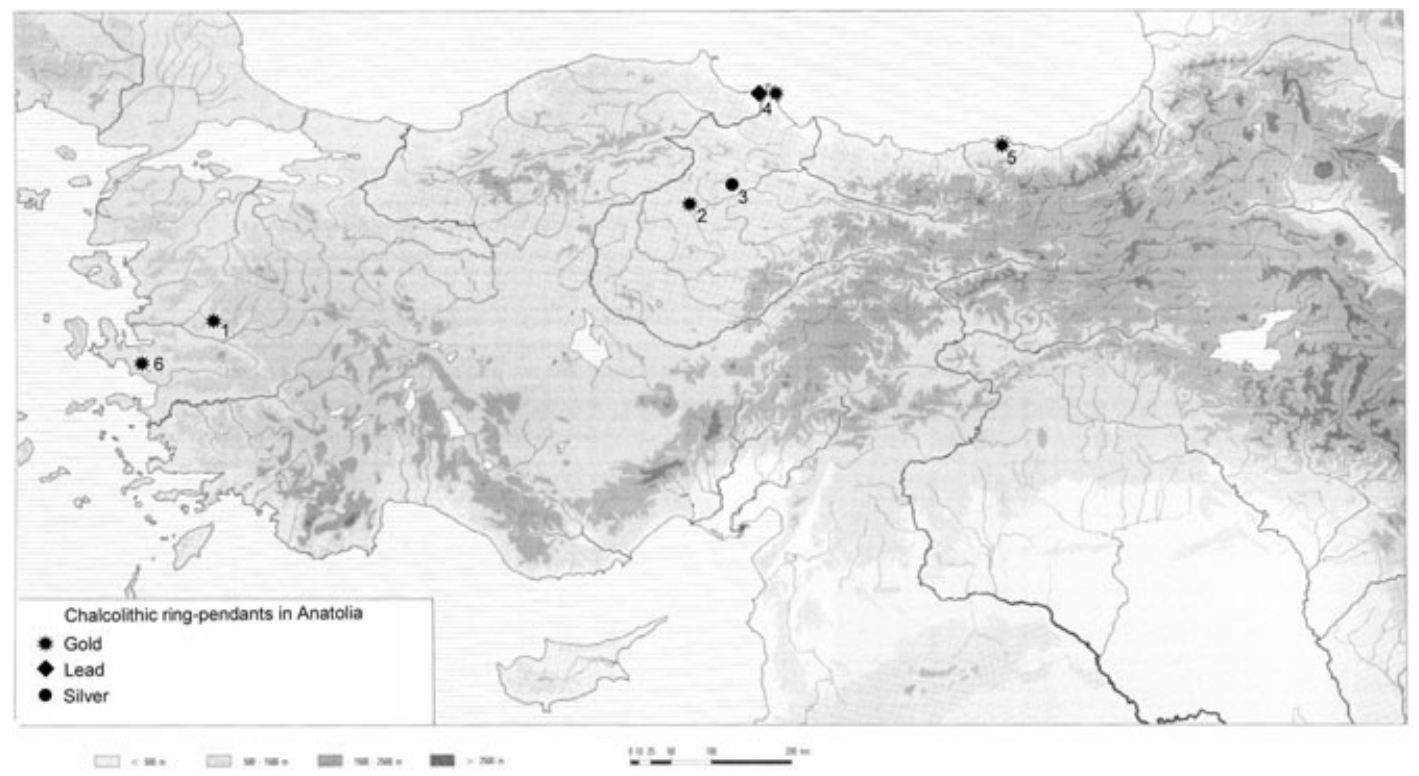

Figure 1

Findspots of ring-shaped pendants in Anatolia: 1) vicinity of Sardis; 2) Kalınkaya; 3) Göller; 4) İkiztepe; 5) vicinity of Trabzon; 6) Bakla Tepe.
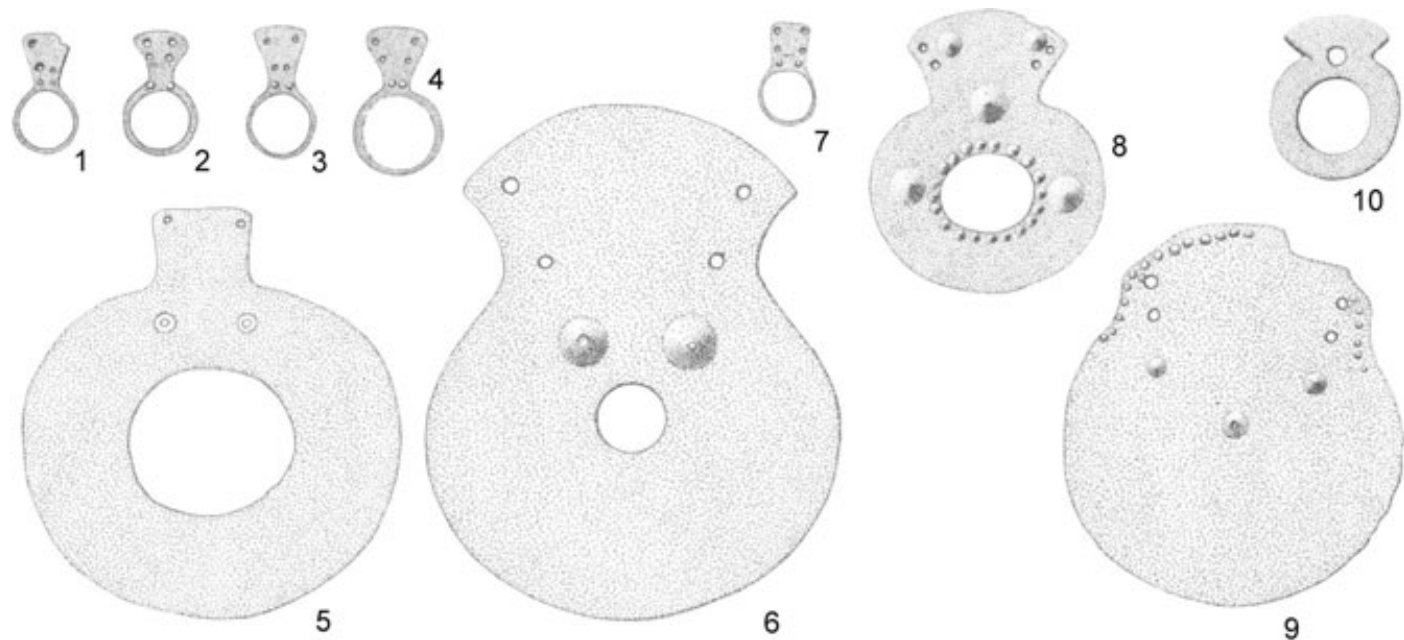

Figure 2

Ring-shaped gold idols from various Chalcolithic findspots in eastern Europe, mainly belonging to the Bodrogkeresztúr horizon: 1, 3) Jászladány; 2, 6) Moigrad, hoard; 4) Oradea; 5) Tîrgu Mureş; 7) Pusztaistvánháza; 8) Progar; 9) Hatvan-Újtelep; 10) Gumelniţa (scale: $1-7,9-10$ at 1:2, 8 at 1:4) (after Müller-Karpe 1974). 

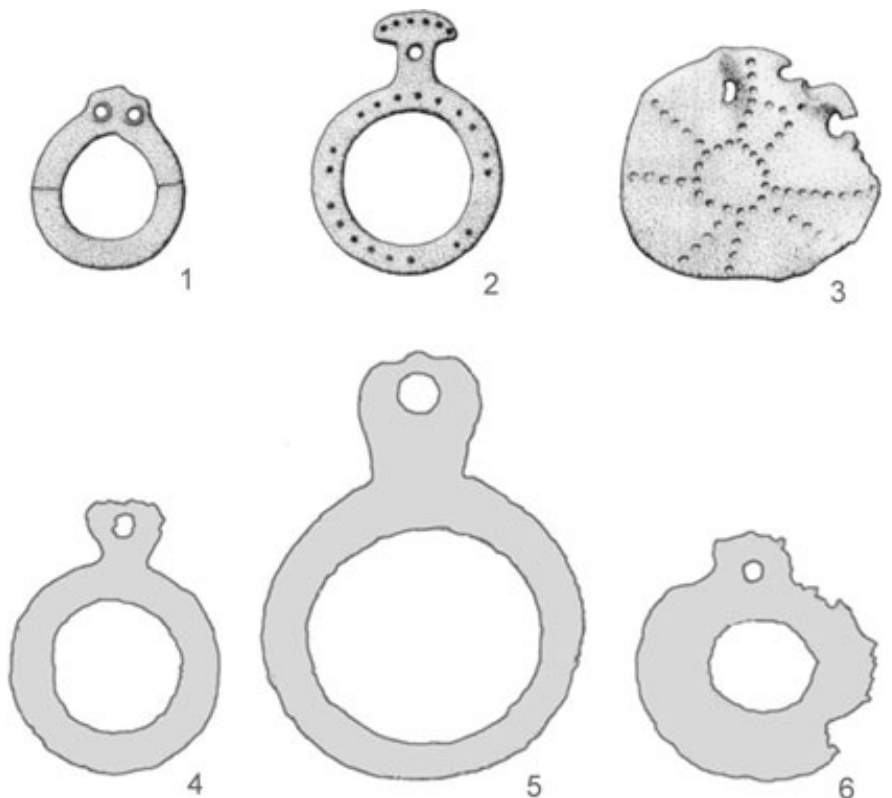

Figure 3

Ring-shaped gold (1, 4-6) and lead pendants (2-3) of European type from the Black Sea coast: 1-3) İkiztepe; 4-6) vicinity of Trabzon (scale: 1-3 at approx. 2:5, 4-6 scale unknown) (after Bilgi 1984 and Rudolph 1978).

large collection of gold jewellery, now part of the Burton Y. Berry collection and said to be from the vicinity of Trabzon but probably not a closed find, includes ring-idols of different size (selection given in Fig. 3, nos. 4-6), but definitely of eastern European fashion (Rudolph 1978, 11-20).

An isolated single idol, allegedly from the looted Early Bronze necropolis of Göller near Oymaağaç in northern Anatolia (Fig. 4, no. 1), is made from silver (Kulaçoğlu 1992, 82 nr. 95, 188 nr. 95; see also Makkay 1989, 42 fig. 2,2, erroneously given as fig. 2,3). Although interpreted as an Early Bronze Age product (Kulaçoğlu 1992, 188), its shape clearly testifies to Chalcolithic Balkan/European traditions. There is no good reason to date it to the end of the third millennium BC, since its exact spatial context is in doubt anyway (see also Maran 2000, 188). The material itself cannot be taken as proof for an Early Bronze Age date either, since silver was utilized in considerable amounts from the Middle and Late Chalcolithic (mid-fourth millennium BC) in the Near East and Anatolia (cf. Esin 1976; Yener 1986; Kohlmeyer 1994; Pernicka, Rehren and Schmitt-Strecker 1998; Zimmermann 2005).

A gold example, again without reliable documentation, is attributed to the findspot 'Kalınkaya', a small settlement and cemetery located some kilometres north of the famous Alaca Höyük in northern Anatolia. The site was investigated in the early Seventies to counteract repeated looting activities (Mellink 1972, 169-70; 1974, 109; Zimmermann 2006). Its idol was also assigned to the later Early Bronze Age, but there is good reason to make it some 1000 years older. Its shape matches the well-known and well-dated Eneolithic specimens from eastern Europe. Furthermore, the extramural cemetery unit of Kalınkaya, where this idol is said to have been found, yielded not only EBA pithos burials and cist graves, but also Chalcolithic flat graves, 

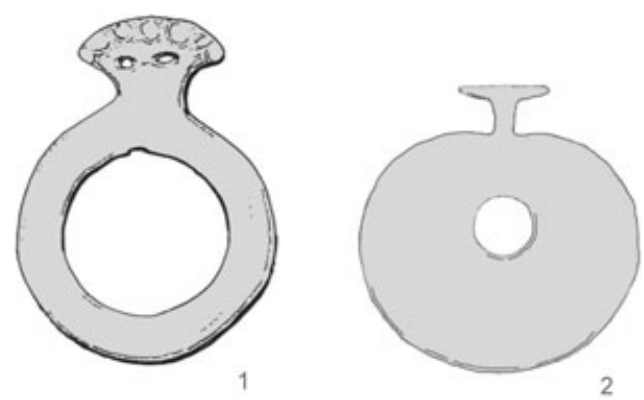

Figure 4

Ring-shaped silver (1) and gold (2) pendants from northern central and western Anatolia: 1) Göller; 2) vicinity of Sardis (scale unknown) (after Kulaçoğlu 1992 and Waldbaum 1983; drawing 1 by Ben Claasz Coockson).

according to the unpublished information obtained from the excavation records in the Museum of Anatolian Civilisations, Ankara (Zimmermann 2006). There is a fair chance that this ringpendant should be associated with one of the looted supine Chalcolithic inhumations described in the excavation diaries (ibid.).

More complicated to interpret is another gold pendant from the 'region of Sardis' in western Anatolia (Fig. 4, no. 2) whose present whereabouts are unknown. Tentatively associated with a trapezoidal gold plaque and an EBA (?) burial context, this ring-pendant is in fact missing the typical flaring 'head', but the upper section seems to be partly bent (Waldbaum 1983, 151-2; pl. 58, 997-9; cf. also Makkay 1989, 42 fig. 2,6.10). An almost identical gold idol of this type comes from the Early Bronze Age necropolis of Bakla Tepe near modern Izmir, allegedly dated to the 'Early Bronze Age II' (Keskin 2004, 148-9, 154 fig. 7 (upper right corner)). Two related small silver and copper (?) pendants are associated with burials dated to the EB I period (Erkanal and Özkan 1999, 124-6, figs. 29-30), representing a reprisal of the earlier Balkan-type pendants. However, gold was widely available in this region, since the nearby Pactolus river (the modern Sart Çayı) contained legendary amounts of placer gold (cf. Yener, Geçkinli and Özbal 1996, 381).

Finally, by far the best evidence, because it is archaeologically documented, comes from one of the largest settlements in the Pontic area of Asia Minor: Ikiztepe, near Bafra on the Turkish Black Sea coast, is a large multiperiod settlement established on the four peaks of its 'Twin Hill'. It has been continuously excavated since the early Seventies, under the auspices of Istanbul University (Alkım, Alkım and Bilgi 1988; 2003; for a conspectus of the evidence see Bilgi 2000, 111-17). Of special interest here, besides the earlier layers of Ikiztepe I and II, is the large cemetery assigned to the Chalcolithic and Early Bronze Age periods. The main bulk of its material has been dated to the late third millennium, or Early Bronze Age III according to Anatolian terminology (cf. Bilgi 1984; 1990; 2004). One gold ring-idol (Fig. 3, no. 1) comes from a domestic context, in Trench ' $\mathrm{D}$ ' and level ' 3 '. Its official date is reported as 'Early Bronze II', to be equated with the second quarter of the third millennium BC (Bilgi 1984, 70, 95 fig. 18,265). Two more ring-pendants (Fig. 3, nos. 2-3) made of lead were associated with flat graves Nos. 192 and 246 from the cemetery (Bilgi 1984, 70 nr. 266, 95 fig. 18,266, 71 nr. 267, 95 fig. 18,267). The use of lead as a raw material, preferably for jewellery and grave goods, is not surprising (cf. Yener 1983), since lead sources that were exploited even in Chalcolithic times are known from the north-east Anatolian Black Sea littoral (Wagner et al. 1986; Koçak 2006, 
40-56), and lead artefacts are attested in several well-documented Chalcolithic contexts in Anatolia (Zimmermann 2005, 192-5).

The very late dating of some İkiztepe domestic and funeral items, despite their characteristically Chalcolithic style and technique, has already provoked a serious challenge by several scholars to the site's official chronology. Parzinger pointed to the considerable vertical stratigraphy of the necropolis, with an accumulated deposit of $6.7 \mathrm{~m}$ that was never sufficiently appraised, and proposed instead a Chalcolithic date for a large number of the metal items that have been published separately (see Parzinger 1993a, 237-8; contra Bilgi 1984; 1990). Other inaccuracies and uncertainties in the preliminary and final publications of Ikiztepe were linked to the complicated stratigraphy of the multiperiod settlement itself, extending over four different summits (cf. above) and yielding largely the remains of wooden architecture, which is unusual for scholars trained in Near Eastern Archaeology to handle (cf. Parzinger 1993b, 219; Thissen 1993, 215-18; Maran 2000, 188).

In general, the suspicion grows that a greater part of the cemetery (whose inventories have so far not been fully published) and parts of the lower domestic strata should be redated to the Late Chalcolithic, or the late fourth millennium BC. Evidence to support this thesis includes the burial practice of the earlier levels in the cemetery: its extended, supine inhumations recalling northern Pontic-Eurasian burial traditions of Chalcolithic Ochre Grave cultures. Most surprisingly, the excavator even mentions stains of 'red soil' (ochre?), but does not draw the logical chronological conclusions (cf. Bilgi 1990, 165-9). The archaic character of the arsenical copper items accompanying the 'ring-idol graves' (Bilgi 1984, 77, 79) also supports a much earlier date than the late Early Bronze Age. Finally, the ring-idols themselves point to a temporal context belonging to the mid- to late fourth millennium $\mathrm{BC}$.

Owing to its location and size, Ikiztepe is of crucial importance to the understanding of cultural dynamics in the prehistoric Pontic region. But further analysis of the findings and the stratigraphy seems necessary in order to refocus the distorted chronological picture we have so far from this key site.

As for the ring-shaped idols, the survey of pendants known so far from modern Turkey, especially the examples from coastal centres like Aegean Bakla Tepe and Black Sea İkiztepe, has shown that styles (and also the connected ideologies? (cf. Maran 2000, 190)) were transferred from Continental Europe and channelled through the Aegean (Maran 2000, 190) and the Black Sea, finally to be adopted by inland Anatolian communities. However, none of the Anatolian items discussed here can be given a date later than the beginning of the Early Bronze Age, since our metal pendants already tie in too well with the firmly established chronological framework of the east/south-east European Chalcolithic. This assumption cannot be challenged even by the 'EB II' grave from Bakla Tepe (above), since the associated inventory (earrings with disc-shaped pendants and multiple-loop spirals) is too undiagnostic to provide a more secure date. Even so, these conclusions have a profound effect on the dating of the lower layers at İkiztepe in particular, including most parts of its cemetery (see also Schoop 2005, 307-14), which should no longer be squeezed into the narrow 'EB II/III' frame.

In conclusion, further critical reappraisals of officially labelled 'third millennium' inventories from contact regions such as Thrace or the Turkish Pontic region should add fresh evidence for a better understanding of Anatolian-European interactions on the threshold of the third millennium BC in Asia Minor. 
Acknowledgements

I am indebted to Marie-Henriette and Charles Gates for proof reading my article and for fruitful discussions, and to Ben Claasz Coockson for preparing the drawings (both Bilkent University).

I am especially grateful to Mr. Hikmet Denizli, Director of the Museum of Anatolian Civilisations, for giving me permission to study the unpublished diaries and related documents of the Kalınkaya expedition, and to the Monuments and Museums section of the Turkish Ministry of Culture for issuing the permit to carry out further research on the Kalınkaya material.

Bilkent University

Faculty of Humanities and Letters

Department of Archaeology and History of Art

06800 Bilkent, Ankara

Turkey

e-mail: zimmer@bilkent.edu.tr

\section{REFERENCES}

Alkim, U.B., Alkim, H. and BILgI, ö. 1988: İkiztepe I. Birinci ve İkinci Dönem Kazılart. The First and Second Seasons' Excavations (1974-1975) (Ankara).

Alkim, U.B., Alkim, H. and BILGi, Ö. 2003: İkiztepe II. Üçuncü, Dördüncü, Beşinci, Altıncı, Yedinci Dönem Kazllarl. The Third, Fourth, Fifth, Sixth and Seventh Seasons' Excavations (1976-1980) (Ankara).

BANKoff, H.A. and Winter, F.A. 1990: The Later Aeneolithic in Southeastern Europe. American Journal of Archaeology 94, 175-91.

BEHRENS, H. 1970: Der Knochenschmuck der Schönfelder Kultur - Nachahmung von südöstlichen Metallvorbildern? Ausgrabungen und Funde 15, 30-3.

BILGI, Ö. 1984: Metal Objects from İkiztepe-Turkey. Beiträge zur Allgemeinen und Vergleichenden Archäologie 6, 31-96.

BILGI, Ö. 1990: Metal Objects from İkiztepe-Turkey. Beiträge zur Allgemeinen und Vergleichenden Archäologie 9-10, 119-219.

BILGI, ö. 2000: İkiztepe Kazıları. In Belli, O. (ed.), Türkiye Arkeolojisi ve İstanbul Üniversitesi (19321999) (Ankara), 111-17.

BILGI, Ö. 2004: İkiztepe Mezarlık Kazıları ve Ölü Gömme Gelenekleri. Anadolu Araştirmalari 17, 25-50. ERKANAL, H. and ÖzKAn, T. 1999: Excavations at Bakla Tepe. In Özkan, T. and Erkanal, H. (eds.), Tahtal Dam Area Salvage Project (İzmir), 108-38.

ESIN, U. 1976: Die Anfänge der Metallverwendung und Bearbeitung in Anatolien (7500-2000 v. Chr.). In Müller-Karpe, H. (ed.), Les débuts de la métallurgie. IX. Congrès UISPP (Nizza, Centre National de la Recherche Scientifique), 209-40.

HANSEN, S. 2005: Neolithic Figurines - East-West. In Lichter, C. (ed.), How did Farming reach Europe? Anatolian-European relations from the second half of the $7^{\text {th }}$ through the first half of the $6^{\text {th }}$ millennium cal. BC. Proceedings of the International Workshop Istanbul, 20-22 May 2004 (Istanbul, Byzas 2), 195-212.

HöcKmann, о. 2003: Zur frühen Seefahrt in den Meerengen. Studia Troica 13, 133-60.

IVAnov, I. and AVramova, M. 2000: Varna Necropolis. The Dawn of European Civilization (Sofia). 
JOVANOvić, B. 1996: Eneolithic gold pendants in South-East Europe: their meaning and their chronology. In Kovács, T. (ed.), Studien zur Metallindustrie im Karpartenbecken und in den benachbarten Regionen. Festschrift Amalia Mozsolics (Budapest), 31-6.

KESKì, L. 2004: M.Ö. III Binyil Sonuna Kadar İzmir Bölgesi Maden İşçiliği. In Çizmeli-Öğün, Z., Sipahi, T. and Keskin, L. (eds.), I-II Ulusal Arkeolojik Araştırmalar Sempozyumu. Anatolia Suppl. No. 1 (Ankara), $141-55$.

KOÇAK, Ö. 2006: Mining at the Central Black Sea Region in the Ancient Period. In Erciyas, D.B. and Koparal, E. (eds.), Black Sea Studies Symposium Proceedings. 16-17 April 2004, Ankara (Istanbul), 39-61.

KOHLMEYeR, K. 1994: Zur frühen Geschichte von Blei und Silber. In Wartke, R.-B. (ed.), Handwerk und Technologie im Alten Orient. Ein Beitrag zur Geschichte der Technik im Altertum. Int. Tagung Berlin 12-15. März, 1991 (Mainz), 41-8.

KULAÇOĞLU, B. 1992: Gods and Goddesses (Ankara).

KYTLICOVÁ, O. 1960: Eneolitické Pohřebiště v Brandýsku. Das äneolithische Gräberfeld in der Gemeinde Brandýsek. Památky Archeologické 51, 442-74.

LICHARDUS, J. 1991: Das Gräberfeld von Varna im Rahmen des Totenrituals des Kodžadermen-GumelniţaKaranovo-VI-Komplexes. In Lichardus, J. (ed.), Die Kupferzeit als historische Epoche (Bonn, Saarbrücker Beiträge zur Altertumskunde 55), 167-94.

MAKKAY, J. 1976: Problems concerning copper age chronology in the Carpathian basin. Copper Age gold pendants and gold discs in Central- and South-East Europe. Acta Archaeologica Hungaria 28, 251-300.

MAKKAY, J. 1989: The Tiszazölös Treasure (Budapest).

MANTU, C.-M. 1993: Anthropomorphic representations from the Precucuteni and Cucuteni cultures. Anatolica 29, 129-41.

MARAN, J. 1998: Die Badener Kultur und der ägäisch-anatolische Bereich. Eine Neubewertung eines alten Forschungsproblems. Germania 76, 497-525.

MARAN, J. 2000: Das ägäische Chalkolithikum und das erste Silber in Europa. In Işik, C. (ed.), Studien zur Religion und Kultur Kleinasiens und des ägäischen Bereiches: Festschrift für Baki Öğ̈̈n zum 75. Geburtstag (Bonn, Asia Minor Studien 39), 179-93.

MELLinK, M. 1972: Archaeology in Asia Minor. American Journal of Archaeology 76, 165-88.

MELLINK, M. 1974: Archaeology in Asia Minor. American Journal of Archaeology 78, 105-30.

MÜLleR-KARPE, H. 1974: Handbuch der Vorgeschichte. Dritter Teilband Kupferzeit (München).

NIKOLOv, v. 1993: Die neolithischen Kulturen Karanovo I, II und III im Kontext und ihre Beziehungen zu Anatolien. Anatolica 29, 167-71.

NIKOLOv, v. 2002: Nochmals über die Kontakte zwischen Anatolien und dem Balkan im 6. Jt. v. Chr. In Aslan, R., Blum, S., Kastl, G., Schweizer, F. and Thumm, D. (eds.), Mauerschau. Festschrift für Manfred Korfmann (Remshalden-Grunbach), 673-8.

NIKolov, v. 2003: The Neolithic and the Chalcolithic Periods in Northern Thrace. TÜBA-AR (Turkish Academy of Sciences Journal of Archaeology) 6, 21-83.

ÖZDoĞAN, M. 1989: Neolithic Cultures of Northwestern Turkey. In Bökönyi, S. (ed.), Neolithic of Southeastern Europe and its Near Eastern Connections. International Conference 1987 Szolnok-Szeged (Budapest, Varia Archaeologica Hungarica II), 201-15.

ÖZDOĞAN, M. 1999: Northwestern Turkey: Neolithic Cultures in Between the Balkans and Anatolia. In Özdoğan, M. and Başgelen, N. (eds.), Neolithic in Turkey. The Cradle of Civilization (Istanbul), 203-24.

PARZINGER, H. 1992: Stollhof-Hlinsko-Hornstaad. Zur absoluten Datierung eines vor-Baden-zeitlichen Horizontes. Germania 10, 241-50. 
PARZINGER, H. 1993a: Studien zur Chronologie und Kulturgeschichte der Jungstein-, Kupfer- und Frühbronzezeit zwischen Karparten und Mittlerem Taurus (Mainz).

PARZINGER, H. 1993b: Zur Zeitstellung der Büyükkaya-Ware: Bemerkungen zur vorbronzezeitlichen Kulturabfolge Zentralanatoliens. Anatolica 19, 211-29.

PERNICKA, E., REHREN, T. and SCHMITT-STRECKER, S. 1998: Late Uruk silver production by cupellation at Habuba Kabira, Syria. In Rehren, T., Hauptmann, A. and Muhly, J.D. (eds.), Metallurgica Antiqua. In Honour of Hans-Gert Bachmann and Robert Maddin (Bochum, Der Anschnitt Beiheft 8), 123-34.

RACZKY, P. 1995: New data on the absolute chronology of the Copper Age in the Carpathian Basin. In Kovács, T. (ed.), Neuere Daten zur Siedlungsgeschichte und Chronologie der Kupferzeit des Karpartenbeckens (Budapest, Inventaria Praehistorica Hungariae VII), 51-60.

Rudolph, w. 1978: A Note on Chalcolithic-Early Bronze Age Jewelry. Indiana University Art Museum Bulletin 1, 6-21.

SCHOOP, U.D. 2005: Das anatolische Chalkolithikum. Urgeschichtliche Studien 1 (Remshalden).

SREJOvić, D. 1993: Der Balkan und Anatolien in der mittleren und jüngeren Steinzeit. Anatolica 29, 269-82.

STEAdMAN, S.R. 1995: Prehistoric Interregional Interaction in Anatolia and the Balkans: An Overview. BASOR 299/300, 13-32.

THISSEN, L. 1993: New Insights in Balkan-Anatolian Connections in the Late Chalcolithic: Old Evidence from the Turkish Black Sea Littoral. Anatolian Studies 43, 207-37.

TODOROvA, H. 1999: Die Anfänge der Metallurgie an der westlichen Schwarzmeerküste. In Hauptmann, A., Pernicka, E., Rehren, T. and Yalçin, Ü. (eds.), The Beginnings of Metallurgy. Proceedings of the International Conference 'The Beginnings of Metallurgy', Bochum 1995 (Bochum, Der Anschnitt Beiheft 9), 237-46.

WAGNER, G.A., PERNICKA, E., SEELIGER, T.C., LORENZ, I.B., BEGEMANN, F., SCHMITT-STRECKER, S., EIBNER, C. and öztunALI, Ö. 1986: Geochemische und isotopische Charakteristika früher Rohstoffquellen für Kupfer, Blei, Silber und Gold in der Türkei. Jahrbuch des Römisch-Germanischen Zentralmuseums 33, $723-52$.

WAldBaum, J.C. 1983: Metalwork from Sardis. The Finds through 1974 (Cambridge, Mass.).

WeisshaAR, H.-J. 1982. Varna und die ägäische Bronzezeit. Archäologisches Korrespondenzblatt 12, 321-9.

YeNER, K.A. 1983: The Production, Exchange and Utilization of Silver and Lead Metals in Ancient Anatolia: A Source Identification Project. Anatolica 10, 1-15.

YENER, K.A. 1986: The Archaeometry of Silver in Anatolia. The Bolkardağ Mining District. American Journal of Archaeology 90, 469-72.

YENER, K.A., GEÇKINLI, E. and ÖZBAL, H. 1996: A brief survey on Anatolian metallurgy prior to 500 BC. In Demirci, Ş., Özer, A.M. and Summers, G.D. (eds.), Archaeometry 94. The Proceedings of the $29^{\text {th }}$ International Symposium on Archaeometry (Ankara), 375-91.

ZANOTTI, D.G. 1984/85: Varna: The Necropolis and the Gold Finds. Talanta 16/17, 53-73.

ZimmermanN, т. 2005: Zu den frühesten Blei- und Edelmetallfunden in Anatolien. Einige Gedanken zu Kontext und Technologie. Der Anschnitt 57, 191-9.

zimmermann, T. 2006: Kalinkaya - A Chalcolithic-Early Bronze Age Settlement and Cemetery in Northern Central Anatolia. First Preliminary Report: The Burial Evidence. Anadolu Medeniyetleri Müzesi 2005 Ylllı̆̆gl. 